\title{
Hydrometallurgical Processing of Manganese Ores: A Review
}

\author{
Alafara A. Baba1,2*, Lateef Ibrahim ${ }^{1 *}$, Folahan A. Adekola ${ }^{1}$, Rafiu B. Bale ${ }^{2}$, \\ Malay K. Ghosh ${ }^{3}$, Abdul R. Sheik ${ }^{3}$, Sangita R. Pradhan ${ }^{3}$, Olushola S. Ayanda ${ }^{4}$, \\ Ismail O. Folorunsho ${ }^{2}$ \\ ${ }^{1}$ Department of Industrial Chemistry, University of Ilorin, Ilorin, Nigeria \\ ${ }^{2}$ Department of Geology and Mineral Sciences, University of Ilorin, Ilorin, Nigeria \\ ${ }^{3}$ Hydro \& Electrometallurgy Department, Institute of Minerals and Materials Technology, Bhubaneswar, India \\ ${ }^{4}$ Department of Chemistry, Faculty of Applied Sciences, Cape Peninsula University of Technology, Cape Town, \\ South Africa \\ Email: ${ }^{*}$ alafara@unilorin.edu.ng, ${ }^{*}$ iblat2004@yahoo.com
}

Received 26 January 2014; revised 2 March 2014; accepted 12 March 2014

Copyright (C) 2014 by authors and Scientific Research Publishing Inc.

This work is licensed under the Creative Commons Attribution International License (CC BY).

http://creativecommons.org/licenses/by/4.0/

c) (i) Open Access

\begin{abstract}
Hydrometallurgy is the most suitable extractive technique for the extraction and purification of manganese as compared to all other techniques including biometallurgy and pyrometallurgical processes. In the hydrometallurgical processing of manganese from its ore, the leach liquors often contain divalent ions such as iron, manganese, copper, nickel, cobalt and zinc along with other impurities which make manganese very difficult to separate. The processes employed for solution concentration and purification in the hydrometallurgical processing of manganese include precipitation, cementation, solvent extraction and ion exchange. Solvent extraction also proves more efficient and it plays vital roles in the purification and separation of the manganese as compared to all other techniques. A detailed review of the various steps involved in the hydrometallurgical manganese processing, concentration and purification processes and newer processes of extraction of manganese from ores and waste materials were discussed.
\end{abstract}

\section{Keywords}

Manganese and Manganese Ores, Hydrometallurgy, Biometallurgy, Pyrometallurgy, Solvent Extraction

\footnotetext{
${ }^{*}$ Corresponding authors.
} 


\section{Introduction}

Manganese (Mn) is a naturally occurring element that is found in rock, soil and water. It is ubiquitous in the environment and comprises about $0.1 \%$ of the earth's crust. Crustal rock is a major source of manganese found in the atmosphere [1]. Manganese rarely exists in its pure, elemental state but instead combines with other elements in nearly 300 different minerals. $\mathrm{Mn}$ is extracted from several economically important oxide minerals including pyrolusite $\left(\mathrm{MnO}_{2}\right)$, psilomelane $\left(\mathrm{BaMn}_{9} \mathrm{O}_{16}(\mathrm{OH})_{4}\right)$, manganite $\left(\mathrm{Mn}_{2} \mathrm{O}_{3} \mathrm{H}_{2} \mathrm{O}\right)$, and wad [2].

Historically, manganese oxide (pyrolusite) has been used in glass making since the time of the pharaohs in Egypt. Manganese was first distinguished as an element in 1774 by the Swedish chemist Carl Wilhelm Scheele while working with pyrolusite. It was isolated the same year by Scheele's associate, Johan Gottlieb Gahn, by burning pyrolusite with charcoal. Manganese had no practical uses until 1839, when it was introduced as an additive in the manufacture of crucible steel. From 1856, the use of ferromanganese in the Bessemer method of steel making made this process very successful [3].

The principal sources of commercial grades of manganese ore for the world are found in Australia, Brazil, China, Gabon, Indian, South Africa, and Ukraine. The major minerals of manganese are pyrolusite $\left(\mathrm{MnO}_{2}\right)$, romanechite (BaMnMn $\left.\mathrm{O}_{16}(\mathrm{OH})_{4}\right)$, manganite $\left(\mathrm{Mn}_{2} \mathrm{O}_{3} \mathrm{H}_{2} \mathrm{O}\right)$ and haussmannite $\left(\mathrm{Mn}_{3} \mathrm{O}_{4}\right)$. Wad is not a definite mineral but it is a term used to describe earthy manganese bearing amorphous material of high moisture content. Common manganese minerals with percentage manganese composition are shown in Table 1.

\subsection{Manganese Ore Deposits}

Over $80 \%$ of the known world, manganese resources are found in South Africa and Ukraine. Other important manganese deposits are in China, Australia, Brazil, Gabon, India and Mexico. The economically mineable manganese deposits are in natural concentrations of 150 - 500 times the average crustal abundance. Manganese is a mobile element, and a variety of geological processes have created natural concentrations of mineable grade and size [4]. Deposits of principal present and future economic importance are of five types, each formed by a distinct set of geological processes [3].

\subsubsection{Sedimentary Deposits}

These deposits are formed by chemical processes that segregated manganese during the deposition of marine sediments. Some sedimentary deposits contain vast quantities of ore because the manganiferous beds are very extensive. The world's largest manganese deposits are sedimentary deposits, including those of the Nikopol District in Ukraine, Chiatura District in Georgia and Kalahari District of South Africa.

\begin{tabular}{ccc} 
Table 1. Manganese minerals with percentage manganese composition [3]. \\
\hline Mineral & Composition & \% Mn composition \\
\hline Bementite & $\mathrm{Mn}_{5} \mathrm{Si}_{6} \mathrm{O}_{15}(\mathrm{OH})_{10}$ & 43.2 \\
Braunite & $\mathrm{Mn}_{2} \mathrm{Mn}_{6} \mathrm{SiO}_{12}$ & 66.6 \\
Cryptomelane & $\mathrm{KMn}_{5} \mathrm{O}_{16}$ & 59.8 \\
Franklinite & $(\mathrm{Fe}, \mathrm{Zn}, \mathrm{Mn}) \mathrm{O}\left(\mathrm{Fe}, \mathrm{Mn}_{2} \mathrm{O}_{2}\right.$ & $10-20$ \\
Haussmannite & $\mathrm{Mn}_{3} \mathrm{O}_{4}$ & 72.0 \\
Manganite & $\mathrm{Mn}_{2} \mathrm{O}_{3} \mathrm{H}_{2} \mathrm{O}$ & 62.5 \\
Manganian calcite & $\left(\mathrm{Ca}_{2} \mathrm{Mn}\right) \mathrm{CO}_{3}$ & 35.4 \\
Romanechite & $\mathrm{Ba} \mathrm{MnMn}_{5} \mathrm{O}_{16}(\mathrm{OH})_{4}$ & 51.7 \\
Pyrolusite & $\mathrm{MnO}_{2}$ & 63.2 \\
Rhodochrosite & $\mathrm{MnCO}_{3}$ & 47.8 \\
Rhodonite & $\mathrm{MnSiO}_{3}$ & 41.9 \\
Wad & $\mathrm{Hydrous} \operatorname{mixture~of~oxides~}$ & Variable
\end{tabular}




\subsubsection{Residual Deposits}

These deposits formed by surface and near surface chemical breakdown and the leaching of impurities from manganiferrous rocks. Such deposits are restricted to humid tropical regions where intense tropical weathering has leached many elements from the rocks, forming a residual concentration of manganiferous material. Deposits of this type are mined extensively in Brazil, India and Gabon. Other examples include Nsuta in Ghana, Tambao in Burkinafaso and Kisenge in Zaire.

\subsubsection{Seafloor Nodules}

This class of manganese ore containing copper, nickel, cobalt and manganese is abundant over vast area of deep ocean basin. They can be considered as a type of sedimentary deposit, but their polymetallic nature and submarine setting and the technical mining problems created by that setting warrant their classification as a distinct deposit type. They occur in irregular single-layer fields at or within a metre of the sediment-water interface. Individual nodules are potato-sized earthy brown to bluish black lumps with a dull luster. They consist of one or more nuclei (shark teeth, whale ear bones, rock fragment or other nodules) surrounded by discontinuous concentric layers of metal oxides and clay.

\subsubsection{Hydrothermal Manganese Deposits}

These are deposits typically found as epithermal and mesothermal veins, and rarely as strata bound deposits. The manganese minerals may form ore-grade concentrations, or may be present as gangue in association with ore minerals of other metals, commonly with Pb-Zn-Ag vein mineralization. Examples include USA, Chile and Kazakhstan.

\subsubsection{Volcanogenic Sedimentary Manganese Oxide Deposits}

Volcanogenic sedimentary manganese oxide deposits are associated with chert and basaltic volcanics in oceanic basins. These deposits are of minor importance in terms of world manganese production, but are the main type found in New Zealand. Worldwide, these deposits are mainly silicate ores, with less common carbonate ores, and rare, oxides ores.

\subsection{Manganese Alloy}

The production of manganese alloy from manganese ore is an energy intensive process and therefore, apart from manganese ore, power plays an important role in the production of manganese alloy. There are basically two processes for the manufacturing of the alloy using either one of high, medium or low grade ore, viz; Blast furnace and submerged electric arc furnace [SEAF]. When manganese ore is converted into manganese alloy, there is a loss of about $15 \%$ of manganese as slag. The remaining $85 \%$ of manganese alloy is further divided and used into crude steel (90\%) and others (10\%). Manganese alloy used for steel making constitute of the following three grades: high carbon ferromanganese (HCFeMn/FeMn), refined grades with medium-carbon (MC) and lowcarbon (LC) and silico-manganese (SiMn).

\subsubsection{Ferromanganese}

Ferromanganese (FeMn) is a combination of iron and manganese, combined in a smelting process to produce this alloy. The usual standard is $80 \%$ manganese plus $14 \%-19 \%$ iron. The balance is carbon and minor impurities. Three grades of ferromanganese include: high carbon ( $80 \% \mathrm{Mn}, 6 \%-8 \% \mathrm{C}, 12 \%-14 \% \mathrm{Fe})$, medium carbon ( $80 \% \mathrm{Mn}, 1 \%$ - 2\% C, $18 \%$ - 19\% Fe) and low carbon ( $80 \% \mathrm{Mn}$, less than $1 \% \mathrm{C}$, more than $19 \% \mathrm{Fe}$ ).

\subsubsection{Silicomanganese}

Silicomanganese (SiMn) is a ferroalloy with high contents of manganese and silicon and is made by heating a mixture of the oxides, manganese oxide $\left(\mathrm{MnO}_{2}\right)$, silicon dioxide $\left(\mathrm{SiO}_{2}\right)$ and iron $\left(\mathrm{Fe}_{2} \mathrm{O}_{3}\right)$ with carbon in a furnace. They undergo a thermal decomposition reaction. It is used as a deoxidizer and an alloying element in steel. The standard grade silicomanganese has carbon levels from $0.05 \%$ to $0.10 \%$ [5].

\subsubsection{Refined Ferromanganese}

Refined ferromanganese (Ref. FeMn) is either produced from high carbon ferromanganese through oxygen 
blown converter (OBC) or from silicomanganese through electrothermic route [6]. The major applications where it is used are stainless steel, heat resistant steel and electric welding electrodes [7]. Table 2 shows the composition and properties of different grades of ferromanganese.

\subsection{Global Production of Manganese and Its Alloys}

China was the largest producer of manganese units (2.7 MMT), followed by South Africa (1.9 MMT), Australia (1.8 MMT), Brazil (1 MMT), Gabon (956 KMT). Other countries produced 1.4 MMT. Manganese ore (wet) production decreased by 22\% in 2009 to 35 million metric tons. This amounted to 11 MMT in manganese units, and yearly decline of 23\%. Table 3 shows major manganese producer countries in 2009.

The total world production of manganese alloy dropped to 11.7 million metric tons (MMT) in 2009 down to $18 \%$ from the previous year. China continued to be the world's largest manganese alloy producing country having produced nearly 6.6 million metric tons. Most of the manganese production is used for steel-king and therefore, demand for manganese is tied to the fortunes of the steel industry and the industrialized nations [3]. The global production of silicomanganese (SiMn) in 2009 was just 7.4 MMT, which was greater than the combined

Table 2. Composition and properties of different ferromanganese grade [6].

\begin{tabular}{|c|c|c|c|c|}
\hline & & High carbon ferromanganese & Refined & Silicomanganese \\
\hline \multicolumn{2}{|c|}{ Chemical formula } & HCFeMn/FeMn & MCFeMn/LC FeMn & SiMn \\
\hline \multicolumn{2}{|c|}{$\% \mathrm{Mn}$} & $65 \%-79 \%$ & $80 \%-81 \%$ & $60 \%-77 \%$ \\
\hline \multirow{4}{*}{$\begin{array}{c}\text { Other } \\
\text { materials }\end{array}$} & $\mathbf{C}$ & $8.0 \% \max$ & $0.1 \%-3.5 \% \min$ & $0.1 \%-2.0 \% \max$ \\
\hline & Si & $2.0 \% \max$ & $10 \%-35 \% \min$ & $2.0 \% \max$ \\
\hline & $\mathbf{P}$ & $0.5 \% \max$ & $0.05 \%-0.35 \% \max$ & $0.15 \%-0.35 \% \max$ \\
\hline & $\mathbf{S}$ & $0.03 \%$ & $0.03 \% \max$ & $0.03 \% \max$ \\
\hline \multicolumn{2}{|c|}{ Produced in BF } & Yes & Produced form HCFeMn via OBC route & No \\
\hline \multicolumn{2}{|c|}{ Produced in EAF } & Yes & SiMn via electrothermic route & Yes \\
\hline \multicolumn{2}{|c|}{ Ore required } & High grade ore & High grade ore & Low grade ore \\
\hline \multicolumn{2}{|c|}{ Used by } & Flat and quality steel products & Flat and quality steel products & Construction Steel \\
\hline \multicolumn{2}{|c|}{ Application } & Normal steel and high carbon steel & $\begin{array}{l}\text { Stainless steel heat resistant steel } \\
\text { and electric welding electrode }\end{array}$ & $\begin{array}{l}\text { Deoxidization agent and } \\
\text { alloying agent to produce steel }\end{array}$ \\
\hline \multicolumn{2}{|c|}{ Ore producer } & South Africa, Gabon and Australia & South Africa, Gabon, and Australia & China, India and Ukraine \\
\hline
\end{tabular}

MCFeMn: medium carbon ferromanganese; BF: blast furnace; EAF: electric arc furnace.

Table 3. Manganese ore product (MMT) in 2009 [8].

\begin{tabular}{ccc}
\hline Countries & Amount (in MMT) & \% produced \\
\hline China & 2.700 & 24.60 \\
South Africa & 1.900 & 17.30 \\
Australia & 1.800 & 16.40 \\
Brazil & 1.000 & 09.11 \\
Gabon & 0.956 & 0.8 .71 \\
Indian & 0.845 & 07.70 \\
Kazakhstan & 0.377 & 03.43 \\
Other countries & 1.400 & 12.75 \\
World total & 10.978 & 100.00 \\
\hline
\end{tabular}


production of high carbon ferromanganese (HCFeMn) and refined ferromanganese (Ref. FeMn), their respective totals being 3.3 MMT and 1.0 MMT [8].

\subsection{Applications of Manganese}

The various end-uses of manganese have different ore requirements giving rise to the classification of manganese ore into metallurgical, chemical and non-metallurgical grades. Haghshenas et al. [6] reported that about $94 \%$ of the manganese ore is converted into manganese alloy, out of which the biggest use of manganese is for the production of steel and cast iron. No satisfactory substitute for manganese in steel production has been identified which combines its relatively low price with outstanding technical benefit. Manganese imparts the following three important properties to steel: sulfur fixing through desulphurizing, reduce oxygen level through deoxidizing, and it enhances mechanical properties, particularly strength and hardness.

\section{Manganese Extractive Metallurgy}

The process of extracting a metal from its ore and refining it is called metallurgical process or simply as metallurgy. Metallurgical processing of an ore include: concentration of the ore, conversion of concentrate to oxides and refining of metals [8]. The concentration of ore can be carried out in two ways, by physical (magnetic separation, hydraulic washing and froth flotation) or chemical (leaching) methods. Conversion of the concentrate to oxides can be by roasting or calcination while metal refine are by liquation, electrolysis or sometimes distillation.

The various types of metallurgy are: pyrometallurgy, biometallurgy/bioleaching and hydrometallurgy.

\subsection{Pyrometallurgy}

This metallurgical process includes smelting and roasting. It involves heating in a blast furnace at temperature above $1500^{\circ} \mathrm{C}$ to convert waste to a form that can be refined. The oxide (waste) is heated with a reducing agent such as carbon in the form of coke or coal, the oxygen of the metal combines with the carbon and is removed as carbon dioxide gas. The waste material in non-metallic part is called gangue. It is removed by means of a flux which, when heated combines with it to form a molten mass called slag. Being lighter than the metal, the slag floats on it and can be skimmed or drawn off [9].

\subsection{Biometallurgy/Bioleaching}

Bioleaching is a technology in which metal ions are extracted from low-grade ores and nodules by direct or indirect actions of micro-organisms. The advantages of bioleaching include the absence of noxious of gases or toxic effluent, simplicity of plant operation and maintenance, economic and simple process requiring low capital and low-operating costs and applicability to various metals [10]-[14]. The principal bacterium in ore leaching is Thiobacillus ferrooxidans, which is capable of oxidizing ferrous iron as well as sulphur compounds. The thermophilic sulfolobus plays a role in leaching at elevated temperature. Most of the biotechnical processes for leaching of metals have been developed using aerobic microorganisms [11]-[13].

However, the highly oxidized metal compounds such as $\mathrm{MnO}_{2}$ and $\mathrm{Fe}_{2} \mathrm{O}_{3}$ can be solubilized by reduction processes [15]. Hence, $\mathrm{Mn}$ and Fe from $\mathrm{MnO}_{2}$ and $\mathrm{Fe}_{2} \mathrm{O}_{3}$ can be recovered by the direct or indirect actions of heterotrophic microorganisms that thrive under micro-aerobic or anaerobic conditions [16]-[20]. In the former case, the microorganisms are capable of utilizing $\mathrm{MnO}_{2}$ as a final acceptor of electrons in the respiratory chain of their metabolism, instead of oxygen [15]. That is, anaerobic heterotrophs such as iron-reducing bacteria, manganese-reducing bacteria, and sulphur-reducing bacteria donate electrons, which are produced by the oxidation of organic substrates to $\mathrm{Fe}_{2} \mathrm{O}_{3}, \mathrm{MgO}, \mathrm{MnO}_{2}, \mathrm{SeO}_{4}$ and $\mathrm{V}_{2} \mathrm{O}_{3}$, and leach the reduced metal ions into the medium [21] [22]. In the second case, the reduction process is associated with the formation of reducing compounds, which are products of their metabolism [18] [19]. The anaerobic bioleaching technology of metals has not been commercialized. This is because it has to be adapted according to each type of metals. Moreover, there is a demand for a less expensive and more environmentally friendly anaerobic bioleaching process [23].

\subsection{Hydrometallurgy}

Hydrometallurgical processes involve the removal of metals from different types of ores, concentrates and waste 
products by aqueous solutions containing different chemical reagents [24]. These processes generally include the following unit operations: roasting (not always), leaching by acids, bases or water, removal of impurities such as iron, separation and recovery processes and refining of recovered metals [25]. In a typical hydrometallurgical flow sheet for preparation of manganese sulphate monohydrate from manganese ore presented by Hariprasad et al. [26], the manganese ore was crushed, ground, sieved and pugged. This was followed by leaching with suitable acid, the leached residue was separated from the liquid by means of a filter and lime added to further remove impurities. The pure liquid after the removal of gypsum was evaporated and crystallized to form manganese sulphate monohydrate.

The innovative hydrometallurgical processing technique for industrial zinc and manganese process residues generally conventional roast-reduction is adopted for the manufacture of electrolytic manganese dioxide (EMD)/ chemical manganese dioxide (CMD) from naturally occurring manganiferrous material. The flow sheet adopted for the manufacture of EMD and CMD from pyrolusite as presented by Nealson and Saffarini [22] involves roasting-reduction, leaching, purification, and electrolysis to obtain EMD and precipitation, washing, calcination and drying to obtain CMD-type 2.

The treatment of these materials, however, encounters certain difficulties. The major difficulties in these contexts included high grade clean ore having $75 \% \mathrm{MnO}_{2}$ is required, the recovery efficiency is below $80 \%$, the process requires certain pollution control measurements as well as the roast reduction process is energy inefficient [22]. To overcome the aforementioned difficulties, another method was proposed [27], which was applied to different grades of pyrolusite, and the results showed that there is no need to use high-reduction process. The strength of this technique lies in the suitability to extract-manganese from different grades of pyrolusite and produces the required quality of battery grade $\mathrm{MnO}_{2}$. Further, the resultant solution can be used for further production of electrolytic manganese metal. The simplified flow sheets developed for the manufacture of EMD and CMD from pyrolusite and manganiferrous bearing material from zinc electromining plant Anode mud were presented in Kirk-Othmer [27].

\section{Basic Steps in Hydrometallurgy}

The actual process of extraction of a metal from its ore depends upon the nature of the ore and the metal. There is no universally operational method for the extraction of metals including manganese. Certain common steps, however, are involved in all metallurgical processes. These steps are:

Mining: Mining is the process of taking out the ores from the mines, when an ore occurs near the surface of the earth and can be directly dug out. Such mining is termed as open-pit mining. When an ore is taken out form greater depths, then the mining is termed deep mining.

Crushing: Extracted ore often occurs in big lumps. It is essential to break it into smaller pieces. The lumps are crushed to smaller pieces by hammering in a hammer mill or by help of a jaw crusher.

Grinding: The crushed ore is then finally grinded to fine powder state in a stamp mill or a pulveriser.

Ore Dressing: The removal of the undesired foreign impurities from the roe is called ore-dressing (beneficiation). Any of the following methods is used for concentrating the ores, the various methods used in ore dressing include:

a) Hand picking: If the impurities present are quite different from the ore and are of large size, these may be removed by hand picking. This method is slow and is generally adopted in the initial stages of concentration.

b) Gravity or levigation separation: When the ore particles are heavier than the gangue particles, the ore is fed into a running stream of water and impurities are washed away and in order to concentrate the ore in bulk, a slanting vibrating wooden table with wooden strips called riffles is introduced in the process, such tables are termed Wilfley tables.

Sometimes in the gravity method, a hydraulic classifier based on the gravity method is used. Ore is agitated by a powerful current of water pushing upwards through the bottom of a conical reservoir. The heavier ore particles settle down and are continuously removed from another opening near the bottom, while the lighter particles are washed away by water.

c) Magnetic separation: This is done especially in the case of hematite ore, were by the powdered ore is dropped on to leather or brass conveyer belt, which moves over two rollers one of these rollers, is magnetic. When the ore passes over the magnetic roller, it sticks to the belt due to the force of attraction and falls nearer due to the force of attraction of the magnetized roller. The gangue falls over readily further away.

d) Froth flotation process: This process is used for concentrating sulphide ores and the ores are preferentially 
wetted by oil while the gangue particles are wetted by water. Powdered ore is mixed with water and a little pine oil and the mixture is vigorously stirred by passing compressed air. The froth, which is produced rises to the surface and carries the ore particles along with it. The gangue is left behind.

Leaching: This is the most important starting point of hydrometallurgical processes [26]. It involves the use of aqueous solutions containing a lixiviant which is brought into contact with a material containing a valuable metal. The lixiviant in solution may be acidic or basic in nature. The type and concentration of the leachant is normally controlled to allow some degree of selectivity for the metal or metals that are to be recovered. In the leaching process, oxidation potential, temperature and $\mathrm{pH}$ of the solution are important parameters and are often manipulated to optimize dissolution of the desired metal component into the aqueous phase.

\subsection{Solution Concentration and Purification}

After leaching, the leach liquor must normally undergo concentration of the metal ions that are to be recovered. Additionally, some undesirable metals may have also been taken into solution during the leach process. The solution is often purified to eliminate the undesirable components. The processes employed for solution concentration and purification include: precipitation, cementation, solvent extraction, ion exchange etc.

\subsubsection{Precipitation of Manganese Compounds}

Precipitation in hydrometallurgy involves the chemical precipitation of both metals and their compounds or of the contaminants form aqueous solutions. Precipitation will proceed through reagent addition, evaporation, $\mathrm{pH}$ change or temperature manipulation until any given species exceeds its limit of solubility. In order to improve efficiency in downstream processes, seeding to initiate crystallization is often used.

\section{1) Hydroxide Precipitation of Manganese}

The precipitation of metals in solutions as metal hydroxides is the most common way to remove metals from solutions in hydrometallurgical processes. The equilibrium of a metal hydroxide precipitation can be expressed by the general equation:

$$
\mathrm{M}^{n+}+n \mathrm{OH} \rightleftharpoons \mathrm{M}(\mathrm{OH})_{n}
$$

The equilibrium constants can be written as:

$$
K_{1}=\frac{1}{\mathrm{M}^{n+}\left[\mathrm{OH}^{-}\right]^{n}}=\frac{1}{K_{s}}
$$

where $K_{s}$ is the solubility product. The equilibria of metal hydroxides precipitation is often represented graphically at $25^{\circ} \mathrm{C}$ [28]. At this temperature, it is predicted that $\mathrm{Fe}^{3+}, \mathrm{Al}^{3+}, \mathrm{Pb}^{2+}$ and $\mathrm{Cu}^{2+}$ can be readily separated from $\mathrm{Mn}^{2+}$ by hydroxide precipitation while separation of $\mathrm{Zn}^{2+}$ from $\mathrm{Mn}^{2+}$ is possible but that of $\mathrm{Co}^{2+}, \mathrm{Ni}^{2+}$ from $\mathrm{Mn}^{2+}$ is difficult by a hydroxide precipitation method due to their closeness on the solubility diagram. Therefore, in hydrometallurgical separation processes, hydroxide precipitation alone does not provide a useful means for separation and recovery of manganese. Generally, hydroxide precipitation in separation and/or recovery of manganese is only useful in some special cases in combination with other methods [29].

One practical strategy is to use hydroxide precipitation for valuable metals together with manganese followed by selective leaching to separate valuable metals from manganese. This is used in the Cawse Laterite Process [30], which comprises the following steps:

a) Precipitation of copper, zinc, nickel and cobalt together with some of the manganese as hydroxides using MgO;

b) Leaching with ammonia in the presence of air and $\mathrm{CO}_{2}$ to selectively dissolve the nickel, cobalt, copper and zinc in the precipitate as ammine complexes in the leach liquor leaving manganese in the leach residue as manganese carbonate or oxides;

c) Nickel and copper are separated from cobalt and zinc by solvent extraction (SX) with LIX841. The nickel is recovered by electro-winning while cobalt, together with zinc, is precipitated as sulphide.

In (CESL) nickel laterite process, a similar principle is used for the separation of nickel and cobalt from manganese with the ammonia carbonate re-leaches [31]. The major advantage of this strategy is the elimination of a large volume of the feed solution at a very early stage form the process circuit by hydroxide precipitation of the metals. However; the operation cost with respect to the re-leach and subsequent separation process is high. 
A different strategy was investigated for separation and recovery of cobalt and manganese from spent bromide oxidation catalysts [32]. Instead of hydroxide precipitation followed by selective leaching with ammonia, a selective precipitation of manganese with ammonia was used. The spent catalysts containing $27 \%-31 \%$ Co, $25 \%-33 \% \mathrm{Mn}, 0 \%-14 \% \mathrm{Fe}$ together with $\mathrm{Cr}$, $\mathrm{Cu}$ and $\mathrm{Ni}$, were leached with $4 \mathrm{M} \mathrm{HCl}$ at $80^{\circ} \mathrm{C}$ for 4 hours. The leach liquor was then purified with successive neutralizations as follows:

a) Addition of $\mathrm{NaOH}$ to remove iron and chromium as hydroxides at $\mathrm{pH} 2$.

b) Addition of ammonia to precipitate manganese from an aerated solution leaving cobalt as a Co(III) hexamine complex in the solution.

c) Recovery of cobalt from this solution by chemical or electrochemical processes.

Compared with the first strategy, the selective precipitation simplifies the process by omitting the re-leach step. However, more ammonia would be used for stabilizing the valuable metals as hexamine complex if the solution volume is large. For the case of laterite processing with a large volume of leach liquor, the first strategy is advantageous in saving expensive ammonia at the expense of comparatively cheap neutralization agent [29].

\section{2) Oxidative Precipitation of $\mathrm{MnO}_{2}$}

Oxidative precipitation of manganese as insoluble manganese dioxides, mainly $\mathrm{MnO}_{2}$, has found a wide application for removal of manganese impurity from $\mathrm{Zn}$, Co and Ni processing circuits. Manganese dioxide $\left(\mathrm{MnO}_{2}\right)$ is a strong oxidizing agent with the standard reduction potential being $1.224 \mathrm{~V}$. It needs a stronger oxidant to oxidize $\mathrm{Mn}(\mathrm{II})$ to higher valence oxides initially $\mathrm{Mn}^{3+}$ and then $\mathrm{MnO}_{2}$ [32]. Various oxidants for $\mathrm{Mn}(\mathrm{II})$ have been studied and applied to the practical processes, including Ozone, $\mathrm{SO}_{2} / \mathrm{O}_{2}$ oxidizing mixture, Caro's acid (peroxy-monosulphuric acid), peroxydisulphuric acid, hypochlorite and chlorate.

A process was reported involving oxidative separation of cobalt and manganese from nickel in a leach solution containing Ni, Co, Fe and Mn [33]. The process involved the following steps:

a) Removing the iron from solution by oxidation and partial neutralization;

b) Removing cobalt and manganese from the solution by oxidation and precipitation at $\mathrm{pH} 1$ to 4 with hypochlorite; and

c) Conventional nickel recovery from the resultant solution.

One problem of using chloric acid or chlorine in the process is its highly corrosive nature and the costs for its control and handling. Chlorine dioxide $\left(\mathrm{ClO}_{2}\right)$ oxidant was used for selective leaching of nickel and cobalt from the precipitated manganese hydroxide [34]. The process is selective because manganese is dissolved and reprecipitated as $\mathrm{MnO}_{2}$ under the strong oxidizing conditions while nickel and cobalt tend to be preferentially leached into the solution.

\section{3) Sulphide Precipitation of Metals from $\mathrm{Mn}^{2+}$ Solution}

The precipitation of metal sulphides and separation is based on different sulphide solubilities of metals at a certain $\mathrm{pH}$ and temperature. Sodium sulphides $\left(\mathrm{Na}_{2} \mathrm{~S}\right)$ or ammonium sulphide $\left(\mathrm{NH}_{4}\right)_{2} \mathrm{~S}$ is usually employed in the precipitation of metal sulphide. The thermodynamic equilibria involved in the sulphide precipitation can be expressed as:

$$
\begin{gathered}
\mathrm{H}_{2} \mathrm{~S}_{(\mathrm{g})} \rightleftharpoons 2 \mathrm{H}^{+}{ }_{(\mathrm{aq})}+\mathrm{S}^{2-}{ }_{(\mathrm{aq})} \\
K_{p}=\frac{\left[\mathrm{H}^{+}\right]^{2}\left[\mathrm{~S}^{2-}\right]}{p \mathrm{H}_{2} \mathrm{~S}} \\
\mathrm{M}^{n+}+n / 2 \mathrm{~S}^{2-} \rightleftharpoons \mathrm{MS}_{n} / 2 \\
K=\frac{1}{\left[\mathrm{M}^{n+}\right]\left[\mathrm{S}^{2-}\right]^{n / 2}}=\frac{1}{K_{s}}
\end{gathered}
$$

where $K_{s}$ is the solubility product of the metal sulphide. These relationships can be written in the form [32]:

$$
\begin{gathered}
\mathrm{pH}=-n / 2\left(\log K_{p}-\log P_{\mathrm{H}_{2} \mathrm{~S}}-\log \left[\mathrm{S}^{2-}\right]\right) \\
\log \left[\mathrm{M}^{n+}\right]=\log K_{s}-n / 2 \log \left[\mathrm{S}^{2-}\right]
\end{gathered}
$$

For a given $P_{\mathrm{H}_{2} \mathrm{~S}}$, each can be plotted on a sulphide solubility diagram. As proposed by Monhemius [28], the 
sulphide solubility diagram at $25^{\circ} \mathrm{C}$, apparently showed that the line of $\mathrm{Mn}^{2+}$ is far to the right hand side of the diagram, indicating that manganese sulphide is more soluble than most other metal sulphides. This offers a theoretical basis for separation of $\mathrm{Mn}^{2+}$ from other metals such as $\mathrm{Cu}^{2+}, \mathrm{Zn}^{2+}, \mathrm{Co}^{2+}, \mathrm{Ni}^{2+}$ and $\mathrm{Fe}^{2+}$ in hydrometallurgical processes, where other metal ions are precipitated as metal sulphides while $\mathrm{Mn}^{2+}$ ions remain in solution.

A controlled sulphide precipitation was used for recovery of copper and nickel-cobalt concentrates from the liquors originating from leaching manganese deep ocean nodules in $\mathrm{FeSO}_{4}-\mathrm{H}_{2} \mathrm{SO}_{4}-\mathrm{H}_{2} \mathrm{O}$ solutions. The metal ions studied include $\mathrm{Co}^{2+}, \mathrm{Cu}^{2+}, \mathrm{Fe}^{2+}, \mathrm{Ni}^{2+}, \mathrm{Mn}^{2+}$ and $\mathrm{Zn}^{2+}$. Promising results were obtained when copper, nickel and cobalt concentrates were precipitated with $5.5 \%$ solution of $\left(\mathrm{NH}_{4}\right) \mathrm{S}$. Copper precipitation was conducted at $\mathrm{pH} 1.0$ and nickel and cobalt precipitation at $\mathrm{pH} 3.0$ at the laboratory temperature and leaving manganese in solution for possible recovery or discharge.

\section{4) Ammonia/Carbonate Precipitation of $\mathrm{MnCO}_{3}$}

Carbonate precipitation of manganese is an important practical process for recovery of manganese. The use of ammonia in the carbonate process, instead of sulphide precipitation, provides an alternative strategy for separation of other valuable metals such as nickel and cobalt form manganese. In this case, manganese precipitates out as solid manganese carbonate while cobalt and nickel are stabilized in the solution as ammine complexes [29].

\subsubsection{Electrolysis}

Electro-winning and electro-refining involve the recovery and purification of metals using electrodeposition of metals at the cathode, and either metal dissolution or a competing oxidation reaction at the anode.

\subsubsection{Ion Exchange}

Chelating agent, natural zeolite, activated carbon, resins and liquid organics impregnated with chelating agents are all used to exchange cations or anions with the solution. Selectivity and recovery are a function of the reagents used and the contaminants present. Ion exchange is a useful method for purification of manganese solution to separate metals including $\mathrm{Cu}, \mathrm{Fe}, \mathrm{Co}, \mathrm{Ni}$ and $\mathrm{Pb}$. Compared with sulphide precipitation method, ion exchange is more environmentally friendly and easier to control. However, a resin has a limited capacity for adsorption of particular metals and therefore more suitable for removal of trace amounts of metal impurities for preparation of highly pure manganese solutions.

Amino-carboxylic amphoteric ion exchangers were tested for the separation of nickel from the $\mathrm{Mn}\left(\mathrm{NO}_{3}\right)_{2}{ }^{-}$ $\mathrm{H}_{2} \mathrm{O}$ system [35]. The examined ion exchanger include aminocarboxylic amphoteric ion exchangers AMF-IT, AMF-2T, AMF-2M, ANKB-35 as well as carboxylic cation exchanger AMF-2T. The ion exchanger AMF-2T was found to be the best for the selectivity of $\mathrm{Ni}(\mathrm{II})$ over Mn(II).

An uptake of copper, nickel, cobalt, lead, iron and manganese from manganese chloride leach solution onto the chelating resin Dowex M4195 in the column experiments has been reported [36]. The solution contained 85 $\mathrm{mg} / \mathrm{L} \mathrm{Cu}, 100 \mathrm{mg} / \mathrm{L} \mathrm{Ni}, 47.5 \mathrm{mg} / \mathrm{L} \mathrm{Co}, 40 \mathrm{mg} / \mathrm{L} \mathrm{Pb}, 6.0 \mathrm{~g} / \mathrm{L} \mathrm{Fe}, 47.59 \mathrm{~g} / \mathrm{L}$ Mn with $1.0 \mathrm{M}$ free acid and $3.6 \mathrm{M}$ total chloride. The results indicated a sequence of affinity of metals in the following order:

$$
\mathrm{Cu}>\mathrm{Ni}>\mathrm{Pb}>\mathrm{Fe}>\mathrm{Co}>\mathrm{Mn}
$$

The results also demonstrated the ability to remove contaminants to an extent, satisfying the quality criteria required for the utilization of the manganese chloride solution for preparing manganese chemicals. The column elution test confirmed that two-stage elution scheme, whereby sulphuric acid was first used to elute iron, nickel and cobalt from the resin, and then a subsequent ammonium hydroxide elution recovered almost all of the copper [36].

\subsubsection{Solvent Extraction of Manganese}

In hydrometallurgical processing of manganese containing materials, the leach liquors often contain divalent ions such as iron, manganese, copper, nickel, cobalt and zinc along with other impurities. Solvent extraction plays vital roles in purification and separation of manganese [29]. The pregnant leach liquor is mixed to emulsification with the stripped organic and allowed to separate. The metal will thus be exchanged from pregnant leach solution into the organic phase. A number of organic solvent extraction reagents have been used for fundamental research, focusing on the phosphorus acid and carboxylic acid cation exchange reagents.

Sato and Nakamura [37] investigated solvent extraction of divalent metals, Mn, Co, Ni, Cu, Zn, Cd, and Hg, 
from sulphuric acid solutions by $\mathrm{D}_{2}$ EHPA (di-2-ethylhexyl phosphoric acid). The distribution coefficient was found to be dependent on the concentrations of acid and $\mathrm{D}_{2} \mathrm{EHPA}$, suggesting that these metals were extracted through a cation-exchange mechanism, according to the following reactions:

$$
\mathrm{Mn}_{(\text {aq) }}^{2+}+2(\mathrm{HA})_{2(\text { org })} \rightleftharpoons \mathrm{MA}_{4} \mathrm{H}_{2 \text { (org) }}+2 \mathrm{H}_{(\text {aq) }}^{+}
$$

where $\mathrm{M}$ denotes $\mathrm{Mn}, \mathrm{Co}, \mathrm{Ni}, \mathrm{Cu}, \mathrm{Zn}, \mathrm{Cd}$ and $\mathrm{Hg}, \mathrm{HA}$ is $\mathrm{D}_{2}$ EHPA in the organic phase and $\mathrm{MA}_{4} \mathrm{H}_{2}$ the metalorganic complex in organic solution. The metal extraction lies in the order:

$$
\mathrm{Zn}>\mathrm{Cd}>\mathrm{Mn}>\mathrm{Cu}>\mathrm{Co}>\mathrm{Ni}>\mathrm{Hg}
$$

In another study carried out by Wang and Nagaosa [19], investigation of the extraction of divalent metal ions using Di-2-methylnonylphosphoric acid $\left(\mathrm{D}_{2} \mathrm{MNPA}\right)$ in heptane at an aqueous ionic strength of $0.10 \mathrm{~mol} / \mathrm{L}$ $\left(\mathrm{NaClO}_{4}\right)$ at $25^{\circ} \mathrm{C}$ was examined. The extraction order of metal is:

$$
\mathrm{Cd} \approx \mathrm{Mn}>\mathrm{Cu}>\mathrm{Co}>\mathrm{Ni}
$$

The metal complexes extracted were found to be all monomeric species by using a slope analysis method. A curve fitting method was used to determine the types of metal-organic complexes extracted. $\mathrm{MnA}_{2} 3 \mathrm{HA}$ and $\mathrm{MnA}_{2}$ 4(HA) complexes were found for Mn(II). The extraction order was also found to depend on the ratio of the molar concentrations of the extractant to the metal in the organic phase as investigated by Thakur [38]. At low loading, the extraction order was established as $\mathrm{Mn}>\mathrm{Cu}>\mathrm{Co}>\mathrm{Ni}$ and the equilibrium reaction proceeded via Equation (10):

$$
\mathrm{Mn}_{(\text {aq) }}^{2+}+2(\mathrm{HA})_{2(\text { org })} \rightleftharpoons \mathrm{M}\left(\mathrm{HA}_{2}\right)_{2(\text { org })}+2 \mathrm{H}^{+}{ }_{\text {(aq) }}
$$

At high loading, the extraction order became $\mathrm{Cu}>\mathrm{Mn}>\mathrm{Co}>\mathrm{Ni}$ and the following equilibrium reaction predominates:

$$
\mathrm{M}_{(\text {aq) }}^{2+}+(\mathrm{HA})_{2(\text { org })} \rightleftharpoons \mathrm{MA}_{2 \text { (org) }}+2 \mathrm{H}_{(\text {(aq) }}^{+}
$$

The extraction of $\mathrm{Mn}, \mathrm{Cu}$, $\mathrm{Co}$ and $\mathrm{Ni}$ in nitric acid medium with versatic 911 acid in benzene was reported [39] [40]. The $\mathrm{MnA}_{2} 4 \mathrm{HA}$ and $\left(\mathrm{MnA}_{2} 2 \mathrm{HA}\right)_{2}$ were observed to be the predominant extracted species of manganese. The extraction reaction of these metals was endothermic and temperature had a significant effect on extraction of $\mathrm{Co}^{2+}$ and $\mathrm{Mn}^{2+}$ [41]. The reported extractions for the separation of manganese from cobalt and nickel are summarized in Table 4.

It is important to note from Table 4, that solvent extraction systems can be applied to both the recovery of manganese and separation of other metal impurities. Di-2-ethylhexylphosphoric acid ( $\left.\mathrm{D}_{2} \mathrm{EHPA}\right)$ has been identified and is the cheapest of the reagents for selective extraction of manganese over other impurities e.g. Ni, Co

\begin{tabular}{|c|c|c|}
\hline Extractant & Remark & Reference \\
\hline $\mathrm{D}_{2} \mathrm{EHPA}$ - phosphoric acid & $\begin{array}{l}\text { Mn removed from Co EW in the pilot } \mathrm{Mn} \mathrm{SX} \text { circuit continuous } \\
\text { operation for separation of } \mathrm{Mn} \text { from Co at } \mathrm{pH} 4.2 \text { extraction order } \mathrm{Zn}_{2} \\
(\mathrm{Ca}>\mathrm{Mn}>\mathrm{Cu}>\mathrm{Co}>\mathrm{Ni}>\mathrm{Mg}) \text {. Optimum } \mathrm{pH} 3 \text { for } \mathrm{Mn} \text { from } \mathrm{Co} \text { at } 23^{\circ} \mathrm{C} \\
\text { optimum } \mathrm{pH} 3.5 \text { for } \mathrm{Mn} \text { from } \mathrm{Ni} \text { at } 40^{\circ} \mathrm{C}-60^{\circ} \mathrm{C} \text {. }\end{array}$ & $\begin{array}{l}\text { Dry et al. [42] } \\
\text { Feather et al. [43] } \\
\text { Hoh et al. [44] } \\
\text { Chang [45] [46] }\end{array}$ \\
\hline PC88A—phosphoric acid & $\begin{array}{c}\mathrm{Fe}(\mathrm{III})>\mathrm{Zn}>\mathrm{Pb}>\mathrm{Cu}>\mathrm{Mn}>\mathrm{Cd}>\mathrm{Ca}>\mathrm{Fe}(\mathrm{II})>\mathrm{Co}>\mathrm{Mg}>\mathrm{Ni}>\mathrm{Mn} \\
\text { over } \mathrm{Mg} \text { and } \mathrm{Ni}\end{array}$ & Dreisinger and Cooper [47] \\
\hline $\begin{array}{l}\text { Cyanex }{ }^{\circledR 272} \text { —phosphonic } \\
\text { acid }\end{array}$ & $\begin{array}{l}\text { Bulong process } \mathrm{Co}, \mathrm{Cu}, \mathrm{Zn} \text { and } \mathrm{Mn} \text { from } \mathrm{Ni} \text { at } \mathrm{pH} 6 \text { and } 50^{\circ} \mathrm{C} \\
\qquad \mathrm{Zn}>\mathrm{Cu}>\mathrm{Mn}>\mathrm{Co}>\mathrm{Mg}>\mathrm{Ca}>\mathrm{Ni}\end{array}$ & $\begin{array}{l}\text { Taylor and Cains [48] } \\
\text { Hubicki and Hubicka [49] }\end{array}$ \\
\hline $\mathrm{D}_{2} \mathrm{EHPA}$ & Separation of $\mathrm{Mn}$ from $\mathrm{Ca}$ and $\mathrm{Ni}$ & Cole $[50]$ \\
\hline PC88A & $\mathrm{D}_{2}$ EHPA best with $\beta \mathrm{Mn} / \mathrm{Co}$ & \\
\hline Cyanex ${ }^{\circledR 272}$ & Max. at pH $4.45 \mathrm{D}_{2} \mathrm{EHPA}>$ PC88A > Cyanex 272 & Devie et al. [51] \\
\hline
\end{tabular}
and Mg. However, $\mathrm{D}_{2}$ EHPA cannot separate manganese from Ca. Synergistic SX systems offer better selective for better selective for purification of manganese solution, but they are generally more costly due to involving expensive synergist such as hydroxyoxime and pyridine carboxylate esters, among others [29].

Table 4. Summary of Mn separation from Co and Ni and recovery from manganese solutions. 


\section{Solvent Extraction of Manganese}

In recent years, several hydrometallurgical processes have been developed for manganese minerals. Haghshenas et al. [25] reported the leaching recovery of zinc, cobalt and manganese from zinc purification residue. The results showed that $50 \mathrm{~g} / \mathrm{L}$ is a suitable acid concentration for the leaching of the HFC cobalt and manganese residual content. The addition of $5 \mathrm{~g} / \mathrm{L} \mathrm{H}_{2} \mathrm{O}_{2}$ as a reductive agent has the best influence on both the cobalt and manganese leaching process. Greater amount of $\mathrm{H}_{2} \mathrm{O}_{2}$ do not have a significant effect.

The study of extraction and purification of Ni, Co and Mn from spent battery material in hydrochloric acid by Li et al. [52], showed that the optimal conditions are that hydrochloric acid concentration is 6 mol/L, reaction temperature is exactly $60^{\circ} \mathrm{C}$, liquid/solid ratio is $8: 1, \mathrm{H}_{2} \mathrm{O}_{2} \mathrm{~mol} /(\mathrm{mes}) \mathrm{mol}=2$ and the leaching time is 2 hours. The results also showed that the dissolution yields of $\mathrm{Ni}$, Co and $\mathrm{Mn}$ could be $95 \%$ weight at least. In this process, some important reactions that occur include the following:

$$
\begin{gathered}
\mathrm{MnS}_{2}+8 \mathrm{H}_{2} \mathrm{O}_{2} \rightarrow 2 \mathrm{Mn}^{4+}+2 \mathrm{SO}_{4}^{2-}+8 \mathrm{H}_{2} \mathrm{O} \\
\mathrm{NiO}+2 \mathrm{H}^{+} \rightarrow \mathrm{Ni}^{2+}+\mathrm{H}_{2} \mathrm{O}
\end{gathered}
$$

Adina et al. [53] carried out the studies concerning the possibilities of manganese recovery from steel slag by $\mathrm{HCl}$ and $\mathrm{HNO}_{3}$ extraction. The result show significant value of manganese separation degree in case of $15 \%$ and $32 \% \mathrm{HCl}$ extraction and $54 \% \mathrm{HNO}_{3}$ extraction as presented in Table 5.

In the case of manganese separation from steel slag by $\mathrm{HCl}$ extraction, increasing $\mathrm{HCl}$ concentration does not bring significant variation of separation degree.

Song et al. [54] carried out reduction of low-grade manganese oxide by biomass roasting. During the reduction and roasting process, the valence state of manganese in ore ranges from high to low state: $\mathrm{MnO}_{2} \rightarrow \mathrm{Mn}_{2} \mathrm{O}_{3}$ $\rightarrow \mathrm{Mn}_{3} \mathrm{O}_{4} \rightarrow \mathrm{MnO}$.

The overall reaction for the process can be written as:

$$
\mathrm{C}_{n} \mathrm{H}_{y} \mathrm{O}_{2}+\mathrm{MnO}_{2} \rightarrow \mathrm{CO}_{2}+\mathrm{MnO}+\mathrm{H}_{2} \mathrm{O}
$$

The product reduced is leached by sulphuric acid and the major chemical reaction is presented as follows:

$$
\mathrm{MnO}+\mathrm{H}_{2} \mathrm{SO}_{4} \rightarrow \mathrm{MnSO}_{4}+\mathrm{H}_{2} \mathrm{O}
$$

Hence, the use of sawdust as reductant reduced the roasting temperature, waste gas emission and energy consumption [54]. The recovery of manganese can reach over $97 \%$ by using sawdust as reductant to deal with lowgrade manganese ore. The optimal conditions are as follows: particle size below $150 \mu \mathrm{m}$, mass ratio of manganese ore to sawdust is $5: 1$, roasting temperature of $500^{\circ} \mathrm{C}$ for 40 minutes, leaching temperature of $60^{\circ} \mathrm{C}$ for 40 minutes, $1 \mathrm{M} \mathrm{H}_{2} \mathrm{SO}_{4}$ and liquid-solid ratio of 10:1.

Yuan et al. [55] studied oxidation and recovery of manganese in the leaching solution from a manganese ore using chloric salts $\left(\mathrm{NaClO}_{3}\right)$ as the oxidant for $\mathrm{Mn}(\mathrm{II})$ in the acidic solutions. Optimum conditions were stepwise addition of the oxidant at a $\mathrm{NaClO}_{3}$ :ore ratio of $0.25: 1(\mathrm{w} / \mathrm{w})$, respectively; an acid:ore ratio of $0.54-0.55: 1$ (w/w), and liquid:solid ratio of 3:1, and a reaction time of 6 hours. More than $90 \%$ of manganese was recovered under the optimum conditions.

Park et al. [34] used chlorine dioxide $\left(\mathrm{ClO}_{2}\right)$ oxidant for selective leaching of nickel and cobalt from the precipitated manganese hydroxide. The process is selective, because manganese is dissolved and precipitated as $\mathrm{MnO}_{2}$ under the strong oxidizing conditions while nickel and cobalt tend to be preferentially leached into the solution.

Cawlfield and Ward [56] used chloric acid $\left[\mathrm{HClO}_{3}\right]$ in a patented process to separate zinc oxide and manganese oxide. The process comprises of the following basic steps:

i) Reacting mixture of zinc oxide and manganese oxide with an aqueous chloric acid solution where in the

Table 5. Optimal conditions of manganese recovery process from steel slag by acid extraction [53].

\begin{tabular}{cccc}
\hline Type of acid & Liquid:solid & Extraction time & Separation optimal value \% \\
\hline $\mathrm{HCl}(15 \%)$ & $10: 1$ & 15 minutes & 84.1 \\
$\mathrm{HNO}_{3}(54 \%)$ & $10: 1$ & 30 minutes & 75.4 \\
\hline
\end{tabular}


chloric as was in molar excess of the manganese oxide to form a chlorine gas phase, a solid phase containing manganese dioxide and a solution phase containing zinc chloride.

ii) Separating the solid phase containing manganese dioxide from the liquid phase.

iii) Recovering the zinc metal from the electrolytic cell.

Wang and Zhou [57] investigated a hydrometallurgical process for the recovery of cobalt from zinc plant residue, and for which ammonium peroxy-disulfate $\left(\left(\mathrm{NH}_{4}\right)_{2} \mathrm{~S}_{2} \mathrm{O}_{8}\right)$ was used for oxidation precipitation of iron and manganese as $\mathrm{MnO}_{2}$. It was found that chloride ion seriously affected the precipitation of manganese, which was attributed to the reduction of the manganese oxide. The standard redox potential of $\mathrm{Mn}_{3} \mathrm{O}_{4} / \mathrm{Mn}^{2+}$ pair is $1.76 \mathrm{~V}$ and that of $\mathrm{Cl}_{2} / \mathrm{Cl}^{-}$pair is $1.39 \mathrm{~V}$. Therefore, the manganese oxide can be thermodynamically reduced to $\mathrm{Mn}^{2+}$ by chloride. The oxidation-reduction reaction between $\mathrm{Mn}^{2+}$ and ammonium peroxodisulphate was proposed to proceed according to Equation (16).

$$
3 \mathrm{Mn}^{2+}+\left(\mathrm{NH}_{4}\right)_{2} \mathrm{SO}_{4}+\mathrm{H}_{2} \mathrm{O} \rightarrow \mathrm{Mn}_{3} \mathrm{O}_{4}+\left(\mathrm{NH}_{4}\right)_{2} \mathrm{SO}_{4}+\mathrm{H}_{2} \mathrm{SO}_{4}+6 \mathrm{H}^{+}
$$

The reaction in Equation (16) indicates that the addition of ammonium peroxy-disulphate will cause a decrease of $\mathrm{pH}$, which may affect the precipitation significantly. The acid can be neutralized by the addition of a dilute sodium carbonate solution. Furthermore, at $\mathrm{pH} 4.0$ - 4.5, precipitation of iron and manganese could be completed by applying sufficient ammonium peroxy-disulphate solution.

Kono et al. [58] studied separation and recovery of $\mathrm{Mn}, \mathrm{Cu}, \mathrm{Ni}$ and $\mathrm{Co}$ from sulphurous acid leach liquor of sea nodules. In this process, $\mathrm{Cu}, \mathrm{Ni}$, $\mathrm{Co}$ and $\mathrm{Mn}$ were completely leached with $0.2 \mathrm{M} \mathrm{H}_{2} \mathrm{SO}_{4}$ while $30 \%$ of iron was undisolved. After oxidation by aeration, $\mathrm{Fe}^{2+}$ was precipitated as $\mathrm{Fe}(\mathrm{OH})_{3}$ at $\mathrm{pH} 4.3-4.4$. Subsequently, manganese was precipitated as $\mathrm{MnCO}_{3}$ by addition of $\left(\mathrm{NH}_{4}\right)_{2} \mathrm{CO}_{3}$, while $\mathrm{Cu}$, $\mathrm{Ni}$ and $\mathrm{Co}$ in the solution were stabilized as ammine-complexes with $\mathrm{NH}_{3}$.

Ritcey and Lucas [59] developed a process for recovery and separation of manganese and zinc from calcined leach liquor. In this process, the separation of copper was accomplished by using LIX63 with very little zinc and no manganese extraction in the equilibrium $\mathrm{pH}$ range of 0.8 - 1.5. After the removal of copper using LIX 63 at a $\mathrm{pH}$ range of 0.8 - 1.5, zinc was extracted at $\mathrm{pH} 3.0$ using $20 \% \mathrm{D}_{2}$ EHPA and $2 \% \mathrm{TBP}$ in kerosene. The maximum separation of $\mathrm{Zn} / \mathrm{Mn}$ was observed at $\mathrm{pH} 3.0$ at an aqueous:organic ratio of 2:1. Any co-extracted manganese was removed by scrubbing with $\mathrm{ZnSO}_{4}$ solution.

Okajima [60] disclosed a process for the treatment of manganese nodules, in which manganese and iron were oxidatively precipitated as respective oxides by aeration of the solution containing $50 \mathrm{~g} / \mathrm{L} \mathrm{Na}_{2} \mathrm{SO}_{3}$. The solid leach, after combining it with the precipitate was used for making ferromanganese containing $43 \% \mathrm{Mn}$ and $16 \%$ Fe. The ferromanganese can be readily enriched for metallurgical applications. An addition of chloride and use of the mixture of $\mathrm{SO}_{2} /$ air improved the separation of iron and manganese.

A process for removing manganese from an aqueous acidic sulphate solution containing zinc and manganese without removing a substantial amount of zinc from the solution was reported by Bolton et al. [61]. The solution had a free acid of 0.1 - $2 \mathrm{M}$, and contained 5 - $170 \mathrm{~g} / \mathrm{L}$ Zn and 1 - $25 \mathrm{~g} / \mathrm{L} \mathrm{Mn}$. The process comprised treating the solution with ozone to oxidize manganese to manganese dioxide and removing manganese dioxide from the solution. The process was further patented for removal of both manganese and chloride ions from aqueous acidic.

Haifeng et al. [62] invented a process for the reductive leaching of manganese from low grade manganese ore in $\mathrm{H}_{2} \mathrm{SO}_{4}$ using cane molasses as reductant. The result showed that manganese dioxide ores cannot be leached by the sulphuric acid directly, but its oxidizing ability gets stronger in the acidic medium. In order to obtain high leaching efficiency of manganese, reducing substances must be added in acidic solution. The chemical reactions which take place during the manganese dioxide dissolution by sucrose or glucose can be described by the following reactions:

$$
\begin{gathered}
24 \mathrm{MnO}_{2}+\mathrm{C}_{12} \mathrm{H}_{22} \mathrm{O}_{11}+24 \mathrm{H}_{2} \mathrm{SO}_{4} \rightarrow 24 \mathrm{MnSO}_{4}+6 \mathrm{CO}_{2}+35 \mathrm{H}_{2} \mathrm{O} \\
12 \mathrm{MnO}_{2}+\mathrm{C}_{6} \mathrm{H}_{12} \mathrm{O}_{6}+12 \mathrm{H}_{2} \mathrm{SO}_{4} \rightarrow 12 \mathrm{MnSO}_{4}+6 \mathrm{CO}_{2}+18 \mathrm{H}_{2} \mathrm{O}
\end{gathered}
$$

At a given temperature and initial acid concentration, when concentration of cane molasses increases, the leaching efficiency of manganese increases and causes the $\mathrm{H}^{+}$concentration to decrease accordingly.

The recovery of zinc and manganese from spent batteries by different leaching systems was carried out by Pagnanelli et al. [63]. The experiment was performed by two acidic reductive leaching; sulphuric acid/oxalic acid and sulphuric acid/hydrogen peroxide. Zinc and manganese oxides can be quantitatively dissolved by sulphuric acid, according to the following equations: 


$$
\begin{aligned}
& \mathrm{ZnO}+\mathrm{H}_{2} \mathrm{SO}_{4} \rightarrow \mathrm{ZnSO}_{4}+\mathrm{H}_{2} \mathrm{O} \\
& \mathrm{MnO}+\mathrm{H}_{2} \mathrm{SO}_{4} \rightarrow \mathrm{MnSO}_{4}+\mathrm{H}_{2} \mathrm{O}
\end{aligned}
$$

On the other hand, the dissolution of manganese oxides such as $\mathrm{Mn}_{2} \mathrm{O}_{3}$ and $\mathrm{Mn}_{3} \mathrm{O}_{4}$ is partial because $\mathrm{MnO}_{2}$ produced is insoluble, according to the following equations:

$$
\begin{gathered}
\mathrm{Mn}_{2} \mathrm{O}_{3}+\mathrm{H}_{2} \mathrm{SO}_{4} \rightarrow \mathrm{MnO}_{2}+\mathrm{MnSO}_{4}+\mathrm{H}_{2} \mathrm{O} \\
\mathrm{Mn}_{3} \mathrm{O}_{4}+\mathrm{H}_{2} \mathrm{SO}_{4} \rightarrow \mathrm{MnO}_{2}+2 \mathrm{MnSO}_{4}+2 \mathrm{H}_{2} \mathrm{O}
\end{gathered}
$$

Therefore, it must be used as reducing agent to leach all manganese contained in the powder. The reduction between manganese dioxide and oxalic acid or hydrogen peroxide in acidic solution occurs as follows:

$$
\begin{gathered}
\mathrm{MnO}_{2}+\mathrm{H}_{2} \mathrm{SO}_{4}+\mathrm{C}_{2} \mathrm{H}_{2} \mathrm{O}_{4} \rightarrow \mathrm{MnSO}_{4}+2 \mathrm{H}_{2} \mathrm{O}+2 \mathrm{CO}_{2} \\
\mathrm{MnO}_{2}+\mathrm{H}_{2} \mathrm{SO}_{4}+\mathrm{H}_{2} \mathrm{O}_{2} \rightarrow \mathrm{MnSO}_{4}+2 \mathrm{H}_{2} \mathrm{O}+\mathrm{O}_{2}
\end{gathered}
$$

The leaching tests showed that Mn extraction yield significantly with oxalic acid concentration. It has a strong positive effect on dissolution of insoluble Mn, sulphuric acid concentration (obviously positive) and the combination of oxalic acid concentration with temperature has a negative effect on the extraction yield (precipitation of dissolved Mn as oxalate). Hydrogen peroxide is a strongly significant factor either for Mn and Zn extraction yield, but it acts in opposite direction. In fact, it is positive for Mn and negative for $\mathrm{Zn}$.

Dissolution kinetic of calcinated manganese ore in acetic acid solutions was studied by Yuksel et al. [64]. The manganese mineral was firstly calcinated for an hour at $700^{\circ} \mathrm{C}$ according to the following reactions:

$$
\mathrm{MnCO}_{3} \rightarrow \mathrm{MnO}+\mathrm{CO}_{2}
$$

The MnO obtained from the calcinations process was dissolved in acetic acid solutions with different concentrations. The dissolution reaction occurs via the following reactions:

$$
\begin{gathered}
\mathrm{CH}_{3} \mathrm{COOH}+\mathrm{H}_{2} \mathrm{O} \rightleftharpoons \mathrm{CH}_{3} \mathrm{COO}^{-}+\mathrm{H}_{3} \mathrm{O}^{+} \\
\mathrm{MnO}+2 \mathrm{H}_{3} \mathrm{O}^{+} \rightarrow \mathrm{Mn}^{2+}+3 \mathrm{H}_{2} \mathrm{O}
\end{gathered}
$$

The overall reaction for manganese can be written as:

$$
\mathrm{MnO}+2 \mathrm{CH}_{3} \mathrm{COOH} \rightarrow \mathrm{Mn}^{2+}+2 \mathrm{CH}_{3} \mathrm{COO}^{-}+\mathrm{H}_{2} \mathrm{O}
$$

It was observed that the dissolution of calcinated rhodochrosite increased with increasing reaction temperature, stirring speed, reaction time and acid concentration and with decreasing particle size and solid to liquid ratio.

Baba et al. [65] carried out the lixiviation study from a Nigerian manganiferrous aluminosilicate mineral in hydrochloric acid. The results showed the extent of the ore dissolution increasing at different $\mathrm{HCl}$ concentrations. The proposed dissolution equation is:

$$
\mathrm{MnO}_{2}+4 \mathrm{HCl} \leftrightarrow \mathrm{MnCl}_{2}+2 \mathrm{H}_{2} \mathrm{O}+\mathrm{Cl}_{2}
$$

With $8.42 \mathrm{M} \mathrm{HCl}$ at $80^{\circ} \mathrm{C}$, about $69.27 \%$ of the $10 \mathrm{~g} / \mathrm{L}$ of the manganiferrous mineral was dissolved within 120 minutes using $<0.09 \mathrm{~mm}$ particle diameter.

Hariprasad et al. [26] proposed Mn recovery from medium grade ore using a waste cellulosic reductant. The used newspaper after charring had a fixed carbon content of 37\%. The major structural components of paper are ligin, hermicellulose and cellulose which makes it a good source of sugars. Concentrated $\mathrm{H}_{2} \mathrm{SO}_{4}$ disrupts the hydrogen bonding of cellulose making it amorphous in nature. De-crystallisation of cellulose results in gelation with acid. This gelatinous mass hydrolyses under dilution. Considering total manganese in the ore present as $\mathrm{MnO}_{2}$, the overall reaction can be represented by:

$$
12 n \mathrm{MnO}_{2}+\left(\mathrm{C}_{6} \mathrm{H}_{10} \mathrm{O}_{5}\right)_{n}+12 n \mathrm{H}_{2} \mathrm{SO}_{4} \rightarrow 12 n \mathrm{MnSO}_{4}+6 n \mathrm{CO}_{2}+17 n \mathrm{H}_{2} \mathrm{O}
$$

$\left(\mathrm{C}_{6} \mathrm{H}_{10} \mathrm{O}_{5}\right)_{n}$ indicates that cellulosic part of paper consists of X-D glucose units.

Manganese extraction of $>90 \%$ can be obtained by leaching the ore at $90^{\circ} \mathrm{C}$ for 8 hours in sulphuric acid medium. With the variation of temperature, the rate of leaching increased with the increase of ore to newspaper ration. 
Zhang et al. [66] introduced a hydrometallurgical process for the recovery of metals from spent secondary batteries. In this study, hydrochloric acid was found as the best leachant. At $80^{\circ} \mathrm{C}$, the efficiency of the cobalt leaching process became more than $99 \%$ in 1 hour. They reported that the applicability of a route for recovery of manganese or other valuable metals from a solution depends on a number of cost sensitive factors, including the concentration of manganese in the solution, levels of other impurities, and purity of final manganese products.

Another work on the treatment of the zinc plant residue has been developed by Wang and Zhou [57]. Their recommended process consisted of six major unit operations including; washing, roasting, leaching, precipitation of iron and manganese, separation of zinc, separation of nickel and precipitation of cobalt.

Dreisinger et al. [67] investigated the recovery of Zn, Co and Mn from Baja Mining Corp’s El Boleo ore body. The process is a whole-ore leach in sea water using a combination of acid oxidation and acid reduction to extract copper, cobalt, zinc and manganese from the ore. They reported that the raffinate from the DSX extraction may be treated to recover manganese by precipitation as manganese carbonate according to the following reactions:

$$
\mathrm{MnSO}_{4}+2 \mathrm{HR}_{(\text {org })}+\mathrm{Na}_{2} \mathrm{CO}_{3} \rightleftharpoons \mathrm{MnR}_{2(\text { org })}+\mathrm{Na}_{2} \mathrm{SO}_{4}+\mathrm{CO}_{2(\mathrm{~g})}+\mathrm{H}_{2} \mathrm{O}
$$

\{DSX manganese scrubbing\}

$$
\begin{gathered}
\mathrm{MnR}_{2(\text { org })}+\mathrm{ZnSO}_{4(\text { aq })} \rightleftharpoons \mathrm{ZnR}_{2(\text { org })}+\mathrm{MnSO}_{4} \\
\mathrm{MnSO}_{4}+\mathrm{Na}_{2} \mathrm{CO}_{3} \rightleftharpoons \mathrm{MnCO}_{3}+\mathrm{Na}_{2} \mathrm{SO}_{4}
\end{gathered}
$$

Gega and Walkowiak [68] carried out the leaching of zinc and manganese from used up zinc-carbon batteries using aqueous sulphuric acid solutions. The results of the examinations indicated that the method of leaching with sulphuric acid for an acid concentration of $2.0 \mathrm{M} \mathrm{H}_{2} \mathrm{SO}_{4}$, liquid/solid ratio of 1:100 and temperature of $60^{\circ} \mathrm{C}$ is suitable for recovering of almost $100 \%$ of $\mathrm{Zn}$ as the aqueous solution of $\mathrm{ZnSO}_{4}$. However, in these conditions, only about $50 \%$ of manganese could be transferred into solution. This is due to the formation of insoluble $\mathrm{MnO}_{2}$ during the leaching process. To solve this, problem, leaching with a moderate reductive agent (like glucose, $\mathrm{Cl}^{-}, \mathrm{SO}_{2}$, hydrogen peroxide, etc.) can be used.

In general, other reported works in the area of manganese hydrometallurgy across the globe is presented in Table 6.

\section{Conclusions}

The decision whether to use hydrometallurgy or pyrometallurgy has been seen from various concerns including environment and economy. In recent years, several hydrometallurgical processes have been developed for manganese extraction from different ores. These processes generally include the following major unit operations: roasting, leaching by acids, bases or water, removal of impurities such as iron, separation and recovery processes and refining of recovered metals [69]. Thermodynamic parameters such as concentration and temperature of the leachant can be used to predict and control the general conditions required for dissolution of secondary resources into water. A large number of studies have been carried out to optimize these processes.

The global steel production and manganese ore production peaked in 2007, whereas Mn alloy production peaked in the following year, i.e. in 2008 at 13.62 million metric tons per annum (MMTPA). However, on yearly basis increase was just 2.46\% [69]. Since last ten years across the globe, the production of manganese ore often occurs simultaneously with that of steel. Moreover, the manganese industry is driven by few companies who are highly disciplined, giving them the power to control the market and production in line with the consumption. The use of manganese in steel production is a double-edged sword, as the metals fortune is intimately tied to the steel industry. Whenever there is a severe downturn in steel-making manganese also suffers [5]. Hence, the need to develop a simple and practicable route for the processing and extraction of manganese from its ores is necessary.

In Nigeria, for instance, the per capital consumption of steel is very low. About $10 \mathrm{~kg}$ or less is the index used to determine the level of industrialization of a country. Statistics showed that Nigeria is lagging behind; and other countries with lesser endowments like Zimbabwe (25 kg), Egypt (42 kg), Algeria (38 kg) and South Africa $(112 \mathrm{~kg})$, are ahead of Nigeria in terms of steel consumption and production. The African Iron and Steel Association (AISA), in May 2002 advise Nigeria Government that the nation could deploy her resources to rise up her level of per capital consumption of steel to $100 \mathrm{~kg}$ [69]. 
Table 6. Summary of some important findings on hydrometallurgical processing of manganese ores.

\begin{tabular}{|c|c|c|}
\hline Author & Work done & Results \\
\hline Haifeng et al. [62] & $\begin{array}{l}\text { The reductive leaching of manganese from } \\
\text { low grade manganese ore in } \mathrm{H}_{2} \mathrm{SO}_{4} \text { using cane } \\
\text { molasses as reductant } 12 \mathrm{MnO}_{2}+\mathrm{C}_{6} \mathrm{H}_{12} \mathrm{O}_{6}+ \\
12 \mathrm{H}_{2} \mathrm{SO}_{4} \rightarrow 12 \mathrm{MnSO}_{4}+6 \mathrm{CO}_{2}+18 \mathrm{H}_{2} \mathrm{O} \text {. }\end{array}$ & $\begin{array}{l}\text { Increase in concentration of cane molasses leads to } \\
\text { leach efficiency of manganese and causes the } \\
\text { concentration to decrease accordingly. }\end{array}$ \\
\hline Pagnanelli et al. [63] & $\begin{array}{l}\text { Recovery of zinc and manganese from } \\
\text { spent batteries by different leaching system. } \\
\text { Sulphuric acid/oxalic acid and } \\
\text { sulphuric acid/hydrogen peroxide. }\end{array}$ & $\begin{array}{l}\text { Low zinc content in the range } 50 \text { to } 120 \mathrm{mg} / \mathrm{L} \text { was } \\
\text { extracted by hydrometallurgical technique. }\end{array}$ \\
\hline Hariphrasad et al. [26] & $\begin{array}{l}\text { Mn recovery from medium grade ore } \\
\text { using a waste cellulosic reductant. } \\
12 \mathrm{MnO}_{2}+\left(\mathrm{C}_{6} \mathrm{H}_{10} \mathrm{O}_{3}\right)_{n} \cdot 12 n \mathrm{H}_{2} \mathrm{SO}_{4} \rightarrow \\
12 n \mathrm{MnSO}_{4}+6 n \mathrm{CO}_{2}+17 n \mathrm{H}_{2} \mathrm{O} \text {. }\end{array}$ & $\begin{array}{l}\text { High \% of Mn extraction ( } 93.1 \%) \text { was obtained under the } \\
\text { following conditions: pulp density } 10 \% \text {, time } 8 \text { hrs, sulphuric } \\
\text { acid } 5 \%(\mathrm{v} / \mathrm{v}) \text {, temperature } 90^{\circ} \mathrm{C} \text { and reductant to ore ratio } 0.5 \text {. }\end{array}$ \\
\hline Baba et al. [65] & $\begin{array}{l}\text { Lixiviation of manganiferrous } \\
\text { aluminosilicate mineral } \\
\text { in hydrochloric acid. }\end{array}$ & $\begin{array}{l}\text { The results showed that the rate increases } \\
\text { with hydrogen }\left(\mathrm{H}^{+}\right) \text {concentration, reaction } \\
\text { temperature but decreases with particle size. }\end{array}$ \\
\hline Yuksel et al. [64] & $\begin{array}{l}\text { Dissolution kinetic of } \\
\text { calcinated manganese ore in } \\
\text { acetic acid solutions. }\end{array}$ & $\begin{array}{l}\text { It was observed that the dissolution of calcinated } \\
\text { rhodochrosite increased with increasing reaction temperature; } \\
\text { stirring speed, reaction time and acid concentration and } \\
\text { decreasing particle size and solid to liquid ratio. }\end{array}$ \\
\hline Jingjing et al. [54] & $\begin{array}{l}\text { Reduction of low grade } \\
\text { manganese oxide ore } \\
\text { by biomass roasting. }\end{array}$ & $\begin{array}{l}\text { The recovery of manganese can reach over } 97 \% \text { by using saw- } \\
\text { dust as reductant. The optimal conditions are as follows; particle } \\
\text { size }\left(150 \mu \mathrm{m} \text {, Mn/sawdust } 5: 1 \text {, roasting temp. } 60^{\circ} \mathrm{C} \text { for } 40 \mathrm{~min} \text {, }\right. \\
\mathrm{H}_{2} \mathrm{SO}_{4} \text { concentration } 1 \mathrm{~mol} / \mathrm{L} \text { and liquid/solid ration } 10: 1 \text {. }\end{array}$ \\
\hline Haghsherias et al. [25] & $\begin{array}{l}\text { Leaching recovery of zinc, } \\
\text { cobalt and manganese from } \\
\text { zinc purification residue. }\end{array}$ & $\begin{array}{l}\text { The results show that } 50 \mathrm{~g} / \mathrm{L} \text { is a suitable acid concentration for } \\
\text { the leaching of the } \mathrm{HFC} \text { cobalt and manganese residual content. } \\
\text { The addition of } 5 \mathrm{~g} / \mathrm{L} \text { of } \mathrm{H}_{2} \mathrm{O}_{2} \text { as a reductive agent has the best } \\
\text { influence on both the cobalt and manganese leaching process. } \\
\text { Greater amount of } \mathrm{H}_{2} \mathrm{O}_{2} \text { do not have a significant effect. }\end{array}$ \\
\hline Kono et al. [58] & $\begin{array}{l}\text { Separation and recovery of } \\
\mathrm{Mn}, \mathrm{Cu}, \mathrm{Ni} \text { and Co from } \\
\text { sulphurous acid leach } \\
\text { liquor of sea nodules. }\end{array}$ & $\begin{array}{l}\text { In this process, } \mathrm{Cu}, \mathrm{Ni}, \mathrm{Co} \text { and } \mathrm{Mn} \text { were completely leached } \\
\text { with } 0.2 \mathrm{M} \mathrm{H}_{2} \mathrm{SO}_{3} \text {. After oxidation by aeration, } \mathrm{Fe}^{2+} \text { was } \\
\text { precipitated as } \mathrm{Fe}(\mathrm{OH})_{3} \text { at } \mathrm{pH} 4.3-4.4 \text {. Subsequently, } \\
\text { manganese was precipitated as } \mathrm{MnCO}_{3} \text { by addition of }\left(\mathrm{NH}_{4}\right)_{2} \\
\mathrm{CO}_{3} \text {, while } \mathrm{Cu} \text {, Ni and Co in the solution were stabilized } \\
\text { as ammine complexes with } \mathrm{NH}_{3} \text {. }\end{array}$ \\
\hline $\begin{array}{l}\text { Gega and Walkowlak } \\
\text { [68] }\end{array}$ & $\begin{array}{l}\text { Leaching of zinc and manganese } \\
\text { from used up zinc-carbon batteries using } \\
\text { aqueous sulphuric acid solutions. }\end{array}$ & $\begin{array}{l}\text { The final optimum conditions for leaching process were } \\
\text { determined to be } 2.0 \mathrm{M} \text { sulphuric acid, a process } \\
\text { temperature of } 60^{\circ} \mathrm{C} \text { and a solid to liquid ratio of } 1: 100 \\
\text { under these conditions } 100 \% \text { of zinc and about } 50 \% \text { of } \\
\text { manganese could be leached in the time of } 1 \text { hour. }\end{array}$ \\
\hline
\end{tabular}

Therefore, improvement on the level of developing a simple route for metal extraction and beneficiation in this area of research needs urgent attention. Hence, no doubt, the use of hydrometallurgical approach in the treatment of manganese ore is preferred due to low cost and safe $\mathrm{H}_{2} \mathrm{~S}$ production for use as a reagent in metallurgical processes, selective metal recovery from metallurgical and waste stream, metals reduction for environmental control, sulphate reduction and removal to meet environmental regulations, sulphate reduction to allow recycle of industrial water, $\mathrm{SO}_{2}$ removal by conversion to elemental sulphur or ammonium sulphate and $\mathrm{CO}_{2}$ or $\mathrm{CO}$ or other greenhouse gasses are not emitted.

\section{Acknowledgements}

A. A. Baba wishes to thank University of Ilorin for permission to honour CSIR-TWAS Fellowship award; Prof. B. K. Mishra, Director, Institute of Minerals and Materials Technology, Bhubaneswar-751013, India for the acceptance as CSIR-TWAS Postdoctoral Fellow and the Management, Academy of Sciences for the Developing World, Trieste, Italy for the Award of 2010 CSIR-TWAS Fellowship for Postdoctoral Research (May, 2011January, 2012). 


\section{References}

[1] Howe, P.D., Malcolm, H.M. and Dobson, S. (2004) Manganese and Its Compound: Environmental Aspect; Monks Wood, United Kingdom. Concise International Ahemical Assessment, Document 63.

[2] Webb, T.C. (2008) Manganese. New Brunswick Department of Natural Resources; Minerals, Policy and Planning Division Mineral Commodity Profile, No. 1, 8 p.

[3] Tony, C. (2011) Mineral Commodity Report 7. Manganese, Institute of Geological and Nuclear Science Ltd.

[4] (1990) Encyclopedia of Science and Technology. 8th Edition, McGraw-Hill, New York, 2730.

[5] Lisa, A.C. (2009) Mineral Industry Surveys. US Geological Survey.

[6] Haghshenas, D.F., Darvishi, D. and Shabesnari, Z.M. (2007) Leaching Recovery of Zinc, Cobalt and Manganese from Zinc Purification Residue. IJE Transaction B, 20, 133-140.

[7] Canterford, J.H. (1985) Sulphuric Acid Leaching of Cobalt Bearing Manganese Wad. Hydrometallurgy, 14, 35-46. http://dx.doi.org/10.1016/0304-386X(85)90004-0

[8] (2010) History of Manganese. International Manganese Institute. Bulletin.

[9] Liew, F.C. (2008) Publication on Pyrometallurgy versus Hydrometallurgy. Engineering Department, TES-AMM, Singapore.

[10] Haines, A.K. and Van Aswegen, P.C. (1990) Process and Engineering Challenges in the Treatment of Refractory Gold Ores. International Deep Mining Conference: Innovations in the Metallurgical Plant, SAIMM, Johannesburg, 103-110.

[11] Boseker, K. (1998) Bioleaching Metal Solubilization by Microorganisms. FEMS Microbiology Reviews, 20, 591-604. http://dx.doi.org/10.1111/j.1574-6976.1997.tb00340.x

[12] Rawlings, D.E. (1998) Industrial Practice and the Biology of Leaching of Metals from Ores. Journal of Industrial Microbiology and Biotechnology, 20, 264-274.

[13] Agate, A.D. (1996) Recent Advance in Microbial Mining. World Journal of Microbiology and Biotechnology, 12, 487495. http://dx.doi.org/10.1007/BF00419462

[14] McNulty, T.P. and Thompson, D.L. (1990) Economic of Bioleaching. In: Ehrlich, H.L. and Brierley, C.L., Eds., Microbial Mineral Leaching, McGraw-Hill Inc., New York, 171-182.

[15] Ehrilch, H.L. (1987) Manganese Oxide Reduction as a Form of Anaerobic Respiration. Geomicrobiology Journal, 5, 423-431. http://dx.doi.org/10.1080/01490458709385977

[16] Schwartz, W. and Naveke, R. (1980) Biotechnische Laugungarmer erze mit heterotrophen mikroorganismen metal. Jahrg, 34, 847-850.

[17] Ehrlich, H.L. (1976) Manganese as an Energy Source for Bacteria. In: Nriagu, J.O., Ed., Environmental Biolgeochemistry, Ann Harbor Science, Michigan, 633-644.

[18] Toro, L., Papponetti, B., Abbruzzese, C., Marrabini, A. and Duarte, M.Y. (1988) Leaching of $\mathrm{Mn}^{2+}$ from Concentrates of $\mathrm{MnO}_{2}$ by Microorganism. In: Costa, M.S., Duarte, J.C. and Williams, R.A.D., Eds., Microbiology of Extreme Environments and Its Potential for Biotechnology, Elsevier, Amsterdam, 395-396.

[19] Papponetti, B., Toro, L., Abbruzzese, C., Marrabini, A. and Duarte, M.Y. (1989) Manganese Leaching from $\mathrm{MnO}_{2}$ Ore by Aspergillus niger: Role of Metabolic Ontermediate. In: Scheiner, B.J., Doyle, F.M. and Kawatra, S.K., Eds., Biotechnology in Minerals and Metal Processing, AIME, Ann Arbor, 33-37.

[20] Abbruzzese, C., Duarte, M.Y., Papponetti, B. and Toro, L. (1990) Biological and Chemical Processing of Low-Grade Manganese Ores. Minerals Engineering, 3, 307-318. http://dx.doi.org/10.1016/0892-6875(90)90126-V

[21] Lovely, D.R. (1994) Dissimilatory Fe (III) and Mn (IV) Reduction. Microbiological Reviews, 55, $259-287$.

[22] Nealson, K.H. and Saffarini, D. (1994) Iron and Manganese in Anaerobic Respiration: Environmental Significance, Physiology and Regulation. Annual Review of Microbiology, 48, 311-343. http://dx.doi.org/10.1146/annurev.mi.48.100194.001523

[23] Young, E., Seung, L., Noh, R., Sukcho, K. and Ryu, H.W. (2001) Leaching of Mn, Co and Ni from Manganese Nodule Using Bioleaching Method, Korea. Journal of Bioscience and Bioengineering, 92, 354-359.

[24] Bazhko, O. (2009) Application of Redox Titration Techniques for Analysis of Hydrometallurgical Solution, South Africa. Hydrometallurgy Conference, 457-463.

[25] Haghshenas, D.F., Darvishi, D. and Shabestari, Z.M. (2007) Leaching Recovery of Zinc, Cobalt and Manganese from Zinc Purification Residue, Iran. IJE Transactions B: Applications, 20, 133-140.

[26] Hariprasad, D., Dash, B., Ghosh, M.K. and Anand, S. (2009) Mn Recovery from Medium Grade Ore Using Waste Cellulosic Reductant. Indian Journal of Chemical Technology, 16, 322-327.

[27] Kirk-Othmer (1983) Encyclopedia of Chemical Technology, Vol. 14. 3rd Edition, 824-895. 
[28] Monhemius, A.J. (1977) Precipitation Diagrams for Metal Hydroxides Sulphates, Arsenates and Phosphates. Transactions of the Institution of Mining \& Metallurgical Section C, 86, C202-C206.

[29] Zhang, W.S. and Cheng, C.Y. (2007) Manganese Metallurgy Review. Part II: Manganese Separation and Recovery from Solution, Australia. Hydrometallurgy, 89, 160-177. http://dx.doi.org/10.1016/j.hydromet.2007.08.009

[30] Manson, P.G., Groutsch, J.V., Mayze, R.S. and White, D.R.S. (1997) Process Development and Plant Design for the Cawse Nickel Project. ALTA Metallurgy Service, Perth, Western Melbourne Australia.

[31] Jones, D. and Moore, R. (2001) The Application of the CESL Nickel Process to Laterites. ALTA Metallurgy Services, Melbourne.

[32] Clark, S.J., Donaldson, J.D. and Khan, Z.I. (1996) Heavy Metals in the Environment. Part VI: Recovery of Cobalt Values from Spent Cobalt/Manganese Bromide Oxidation Catalysts. Hydrometallurgy, 40, 381-392. http://dx.doi.org/10.1016/0304-386X(95)00007-4

[33] Ferron, C.J. (2003) Selective Precipitation from Nickel Recovery from Ore Leach Solution Containing Co, Fe and Mn. CA Patent No. 2396972.

[34] Park, K.H., Kim, H.I. and Das, R.P. (2005) Selective Acid Leaching of Nickel and Cobalt from Precipitated Manganese Hydroxide in the Presence of Chlorine Dioxide. Hydrometallurgy, 78, 271-277. http://dx.doi.org/10.1016/j.hydromet.2005.05.001

[35] Kononova, O.N., Kholmogorov, A.G., Kachin, S.V., Mytykh, O.V., Kononov, Y.S., Kalyakina, O.P. and Pashkov, G.L. (2000) Ion Exchange Recovery of Nickel from Manganese Nitrate Solutions. Hydrometallurgy, 54, 107-115.

[36] Diniz, C.V., Ciminelli, V.S.T. and Doyle, F.M. (2005) The Use of the Chelating Resin Dowex M-4195 in the Absorption of Selected Heavy Metal Ions from Manganese Solutions. Hydrometallurgy, 78, 147-155. http://dx.doi.org/10.1016/j.hydromet.2004.12.007

[37] Sato, T. and Nakamura, T. (1985) Solvent Extraction of Divalent Metals from Sulphuric Acid Solutions by 312.

[38] Thakur, N.V. (1998) Extraction Studies of Base Metals (Mn, Cu, Co and Ni) Using the Extractant 2-Ethylhexyl-2Ethylhexyl Phosphonic Acid. PC88A. Hydrometallurgy, 48, 125-131.

[39] Shibata, J., Izutani, M., Kuwahara, H. and Nishimura, S. (1974) Solvent Extraction of Manganese with Versatic Acid 911. Nippon Kinzoku Gakkaishi, 38, 847-852.

[40] Shibata, J. and Nishimura, S. (1975) Studies on the Extraction Equilibria of Cu, Ni, Co and Mn with Versatic Acid 911. Transactions of the Japan Institute of Metals, 20, 111-118. http://dx.doi.org/10.2320/matertrans1960.20.111

[41] Mukai, S., Shibata, J. and Nishimura, S. (1975) Effect of Temperature on the Solvent of Metal Ions with Versatic Acid 911. Nippon Kinzoku Gakkaishi, 39, 976-981.

[42] Dry, M.J., Irio, G., Jacobs, D.F., Cole, P.M., Feather, A.M., Sole, K.C., Engelbrecht, J. and Matchett, K.C. (1998) $\mathrm{Cu} / \mathrm{Co}$ Tailings Treatment Project, Democratic Republic of Congo. ALTA Nickel/Cobalt Conference, ALTA, Metallurgical Services, Melbourne.

[43] Feather, A.M., Sole, K.C. and Dreisinger, D.B. (1999) Pilot-Plant Evaluation of Manganese Removal and Cobalt Purification by Solvent Extraction. ISEC: International Solvent Extraction Conference, 2, 1443-1448.

[44] Hoh, Y.C., Chuang, W.S., Lee, B.D. and Chang, C.C. (1984) The Separation of Manganese from Cobalt by $\mathrm{D}_{2}$ EHPA. Hydrometallurgy, 40, 65-76.

[45] Cheng, C.Y. (1999) Separation of Manganese from Nickel and Cobalt by Solvent Extraction. Nickel/Cobalt Pressure Leaching and Hydrometallurgy Forum, ALTA Metallurgical Services, Melbourne.

[46] Cheng, C.Y. (2000) Purification of Synthetic Laterite Leach Solution by Solvent Extraction Using $\mathrm{D}_{2}$ EHPA. Hydrometallurgy, 56, 369-386. http://dx.doi.org/10.1016/S0304-386X(00)00095-5

[47] Dreisinger, D.B. and Cooper, W.C. (1984) The Solvent Extraction Separation of Cobalt and Nickel Using 2-Ethylhexyl Phosphonic Acid Mono-2-Ethylhexyl Ester. Hydrometallurgy, 56, 369-386.

[48] Taylor, A. and Cairns, D. (1997) Technical Development of the Bulog Laterite Treatment Project. Nickel and Cobalt Pressure Leaching and Hydrometallurgy Forum, ALTA Metallurgical Services, Melbourne.

[49] Hubicki, Z. and Hubicka, H. (1996) Studies on the Extraction Process of Nickel (II) Sulphate Purification Using Cyanex 272. Hydrometallurgy, 40, 65-76. http://dx.doi.org/10.1016/0304-386X(94)00058-B

[50] Cole, P.M. (2002) The Introduction of Solvent-Extraction Steps during Upgrading of a Cobalt Refinery. Hydrometallurgy, 64, 69-76. http://dx.doi.org/10.1016/S0304-386X(02)00013-0

[51] Devi, N.B., Nathsarma, K.C. and Chakravortty, V. (2000) Separation of Divalent Manganese and Cobalt Ions from Sulphate Solutions Using Sodium Salts of $\mathrm{D}_{2}$ EHPA, PC88A and Cyanex 272. Hydrometallurgy, 54, 117-131.

[52] Li, J.H., Li, X.H., Hu, Q.Y., Wang, Z.X., Zheng, J.C., Wu, L. and Zhang, L.X. (2009) Study of Extraction and Purification of Ni, Co and Mn from Spent Battery Material. Hydrometallurgy, 99, 7-12. 
[53] Adina, B., Iovi, A. and Negrea, P. (2005) Studies Concerning the Possibilities of Manganese Recovery from Steel Slag by $\mathrm{HCl}$ and $\mathrm{HNO}_{3}$ Extraction. Chemical Bulletin of Politehnica University of Timisoara, 50, 130-133.

[54] Song, J.J., Zhu, G.C., Zhang, P. and Zhao, Y.N. (2010) Reduction of Low-Grade Manganese Oxide Ore by Biomass Roasting, China. Acta Metallurgica Sinica, 23, 223-229.

[55] Yuan, M., Chen, K. and Qiu, G. (2000) Study on Process for Preparation of Active Manganese Dioxide from Natural Manganese Ore. (3) Oxidation and Recovery of Manganese (II) Ion in Leaching Solution. Multipurpose Utilization of Mineral Resources, 1, 16-18.

[56] Cawlfield, D.W. and Ward, L.R. (1995) Integrated Process of Using Hydrochloric Acid to Separate Zinc Oxide and Manganese Oxide. US Patent No. 5411643.

[57] Wang, Y. and Zhou, C. (2002) Hydrometallurgical Process for Recovery of Cobalt from Zinc Plant Residue. Hydrometallurgy, 63, 225-234. http://dx.doi.org/10.1016/S0304-386X(01)00213-4

[58] Kono, Y., Mizota, T. and Fujii, Y. (1986) A Precipitation Separation Method for Copper, Nickel, and Cobalt Recovery from Sulfurous Acid Leach Liquor of Sea Manganese Nodules. Nippon Kogyo Kaishi, 102, 585-590.

[59] Ritcey, G.M. and Lucas, B.H. (1971) Purification of Manganese Solutions Containing Copper and Zinc by LiquidLiquid Extraction Using Di-(2-ethylhexyl) Phosphoric Acid. Canadian Metallurgical Quarterly, 10, 223-228. http://dx.doi.org/10.1179/cmq.1971.10.3.223

[60] Okajima, Y. (1977) Process for Treating Manganese Nodules. US Patent No. 4029498.

[61] Bolton, G.L., Sefton, V.B. and Zubryckyj, N. (1982) Removal of Manganese and Chloride Ions from Aqueous Acidic Zinc Sulfate Solutions for the Recovery of Zinc. EP Patent No. 66024.

[62] Su, H.F., Wen, Y.X., Wang, F., Sun, Y.Y. and Tong, Z.F. (2008) Reductive Leaching of Manganese from Low-Grade Manganese Ore in $\mathrm{H}_{2} \mathrm{SO}_{4}$ Using Cane Molasses as Reductant, China. Hydrometallurgy, 93, 136-139. http://dx.doi.org/10.1016/j.hydromet.2008.01.001

[63] Pagnanelli, F., Furlani, G., Ferella, F., De Michelis, I., Beolchini, F., Veglio, F. and Toro, L. (2005) Recovery of Zinc and Manganese from Spent Batteries by Different Leaching Systems. Italy.

[64] Yuksel, A., Seda, K. and Julide, K. (2007) Dissolution Kinetics of Calcinated Manganese Ore in Acetic Acids Solutions. C. B. U. Journal of Science, 3, 81-88.

[65] Adekola, F.A., Baba, A.A., Bale, R.B., Abdus-Salam, N., Eletta, O.A.A. and Olajide, F.T. (2009) Lixiviation of Manganiferrous Aluminosilicate Mineral in Hydrochloric Acid. African Journal of Pure and Applied Chemistry, 3, 183188.

[66] Zhang, P., Yokoyama, T., Itabashi, O., Suzuki, T.M. and Inoue, K. (1998) Hydrometallurgical Process for Recovery of Metal Values from Spent Lithium-Ion Secondary Batteries. Hydrometallurgy, 47, 259-271. http://dx.doi.org/10.1016/S0304-386X(97)00050-9

[67] Dreisinger, D., Gluck, T., Marte, K., Hamm, R., Molnar, R., Lu, J. and Xie, F. (2010) The Recovery of Zn, Co and Mn from Baja Minig Corp’s EL Boleo Ore Body. TMS, Hoboken, 623-636.

[68] Gega, J. and Walkowiak, W. (2011) Leaching of Zinc and Manganese from Used-Up Zinc-Batteries Using Aqueous Sulphuric Acid Solutions, Poland. Physicochemical Problems of Mineral Processing, 46, 155-162.

[69] Billiton, B.H.P. (2011) Roskill, CRU. http://www.ideasfirst.in 